\title{
自動車用多色表示装置の可読性
}

准員 三浦 弘雅 (名城大学) 正会員 和田 隆 (名城大学) 専門会員 岡林 繁 (名城大学) 専門会員 畑田 豊彦 (東京工芸大学)

\section{Legibility of Multi-color Displayed Images in Automotive Use}

Associate Member Hiromasa Miura (Meijo University), Member Takashi Wada (Meijo University),

Fellow Member Shigeru Okabayashi (Meijo University) and

Fellow Member Toyohiko Hatada (Tokyo Institute of Polytechnics)

KEYWORDS : automobile, display, color, spatial frequency, legibility

\section{1. はじめに}

ITS(Intelligent Transport Systems)に代表される自動車の情 報高度化に伴い, ナビゲーション表示装置のように多くの情報を 表現するため, 有彩色表示像が広く用いられている.

表示装置を車載して実際に走行し, 同一画面に同一輝度で有彩 色表示像を観察すると, 「赤色表示像は緑色表示像よりよく読め る」1)と多くのドライバが報告することがある，また，多色蛍光表 示管を用いたデジタル表示装置においては, 強い太陽光が表示面 に入射してウォッシュアウトが起こると, 表示部輝度と非表示部 輝度のコントラスト比が低下し, 表示が読みにくくなるといった 現象を体験する.この場合にも「赤色は緑色に比べると輝度を上げ なくても読める」ことが知られている2）。

輝度值を定義している分光視感効率特性 3 )を考虑すると, 輝度 が同一であるならば「緑色光と赤色光のどちらも同じように読め る」はずにもかかわらず，現実には必ずしもそうではない，これを 仮に「色相の差異による知覚の不均一」と呼ぶことにすると,「色相 の差異による知覚の不均一」は, 自動車の有彩色表示像の可読性を 輝度值のみ考慮して規定すると, ある色相の情報は読みとること ができて他の色相の情報は読みとれないという, 自動車用途とし て大きな問題を引き起こす可能性がある.

本報告では, 有彩色表示像の可読性と輝度の関係を短時間視標 呈示実験によって明らかにするとともに,「色相の差異による知覚 の不均一」と分光視感効率特性との整合性を空間周波数特性の観 点から実験評価した。

\section{2. 実験 1 -短時間視標呈示実験}

\section{1 実験系と実験装置}

表示像と背景の輝度コントラストが高ければ色相によらずドラ イバは表示像を十分読みとることができるはずである。「色相の差 異による知覚の不均一」は表示像が低コントラストになる条件で 実験考察すればよい.

本実験では, 二種類の低コントラスト条件を実験室で再現して 「色相の差異による知覚の不均一」をもたらす視覚メカニズムを調 ベた，一つ目は，周囲が比較的暗く表示像が低コントラストの条 件(低照度·低輝度条件)であり, 二つ目は明るい状況で太陽光等の

脚注 : 本速報の一部は平成 14 年度照明学会全国大会で発表.
照射によって表示像と背景の輝度コントラストが低下する条件 (高照度·高輝度条件)である.

自動車内に表示された情報に対する, 運転時のドライバの情報 受容を考え, 実験は短時間視標呈示法により行った. 視標呈示時 間は, 自動車運転時のドライバの表示像への視点停留時間を参考 に 0.5 秒とした ${ }^{4)}$. 実験は外来光の影響を受けないように光学暗 室内で行った. 低照度·低輝度条件の場合は, 表示装置にカラー CRT を用いた(図 1). 高照度·高輝度条件の場合は, 表示像面の輝 度を高くするために高照度液晶プロジェクタと透過型スクリーン を用いた．実験条件を表 1 にまとめる.

表 1 実験条件

Table 1 Experimental conditions.

\begin{tabular}{ccc}
\hline 項目 & 低照度·低輝度条件 & 高照度·高輝度条件 \\
\hline 色相 & 赤, 緑, 青 & $\leftarrow$ \\
形状 & スネレン図形対 & $\leftarrow$ \\
輝度 & $0.4 \sim 10\left(\mathrm{~cd} / \mathrm{m}^{2}\right)$ & $70 \sim 360\left(\mathrm{~cd} / \mathrm{m}^{2}\right)$ \\
背景 & 黒灰色 & $\leftarrow$ \\
サイズ $\left(a^{*}\right)$ & $0.26 \sim 0.8(\mathrm{mrad})$ & $\leftarrow$ \\
表示面照度 & $1(\mathrm{~lx})$ & $10000(\mathrm{~lx})$ \\
\hline \multicolumn{2}{c}{ * 2 は被験者から見た視覚で表したサイズ(図 2 参照 $)$}
\end{tabular}

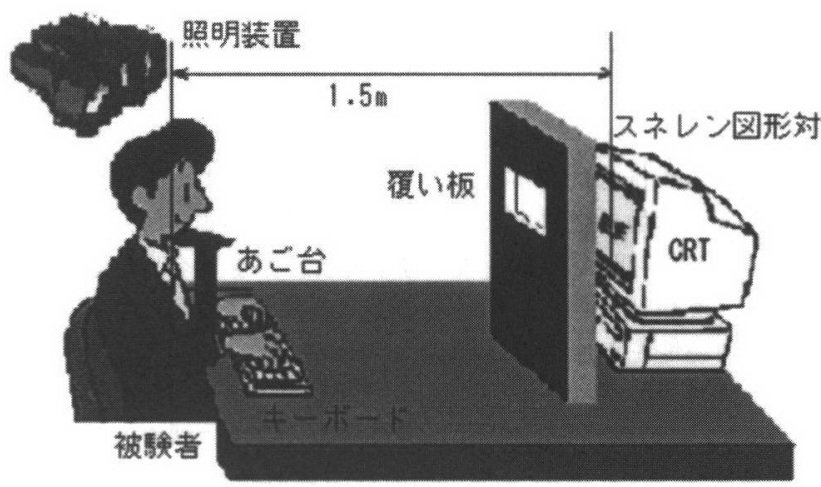

図 1 実験装置(低照度·低輝度条件)

Fig.1 Experimental set up (low illuminance - low luminance condition). 
実験は同一条件でスネレン図形対(図 2)を 100 回呈示し, スネレ ン図形対の開口方向を答えさせた．正答した比率から正答率 $(\%)$ を定義し，可読性の指標として用いた。

正答率は被験者の視機能によって異なるので, 緑色の視標を用 いて低照度·低輝度条件は $1 \mathrm{~cd} / \mathrm{m}^{2}$ で, 高照度·高耀度条件は 100 $\mathrm{cd} / \mathrm{m}^{2}$ で正答率が $50 \%$ になよう, 予め視標サイズを視機能に応じ て基準化した. 被験者は色覚正常かつ自動車免許を有する 20 代の 男女 20 名.

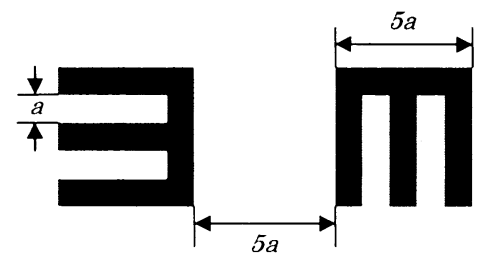

aは被験者から見た視角で表したサイズ

$(0.26 \sim 0.8 \mathrm{mrad})$

図 2 指摽として用いたスネレン図形対

Fig. 2 Pair of Snellen figures used in the experiment.

\section{2 結果}

（1）低照度·低輝度条件之高照度·高輝度条件について，赤色表 示像, 緑色表示像, 青色表示像のそれぞれの輝度と正答率の 関係を図 $3 ， 4$ に示す。横軸は輝度值の対数軸とした。デー 夕は全被験者の平均の正答率である.

可読性の閥值を正答率 $50 \%$ の值と考えると, 低照度·低輝度 条件, 高照度·高輝度条件のどちらも青色表示像の必要輝度值 が最も高く, 緑色表示像, 赤色表示像の順に低くなっている. 表示像がすべて同一輝度であるとすると, 赤色表示像の正答率 が最も高く, 緑色表示像, 青色表示像の順に低下し, 色相によ つて可読性の程度が異なる「色相の差異による知覚の不均一」 が発生していることが分かる. また, 赤色表示像が分光視感効 率の高い緑色表示像がより読みやすいという, 実車走行時のド ライバの報告とよく符合する結果が得られた.

（2）「色相の差異による知覚の不均一」の要因として背景部と表 示部の色差によるものと仮定して, 低照度·低輝度条件の実験 結果で輝度值 $1 \mathrm{~cd} / \mathrm{m}^{2}$ の表示像について, 色差 $\left(L^{*} a^{*} b^{*}\right)$ を算出 した ${ }^{5}$. 表 2 に示す様に, 背景色之表示像の色差 $\left(L^{*} a{ }^{*} b\right)$ の大 小と正答率の高さの間には有意な相関は認められなかった。

\section{3. 実験 2 -色相別空間周波数特性-}

A.Roorda や D.Williams, 坂田らの研究 6) 8)では, 網膜の中心 窩近傍では, 赤色, 緑色, 青色の光に感度が高い 3 種類の錐体 (L, $\mathrm{M}, \mathrm{S}$ )が分布し, その分布密度は $\mathrm{L}$ 錐体(長波長の光に感じる錐体) の密度は高く, $\mathrm{S}$ 錐体(短波長の光に感じる錐体)の密度はもっとも 低いことが報告されている. 本実験のように, 視点を移動して中 心視野で表示像を受容する場合には，3 種類の錐体(L，M，S)の 分布密度に依存して有彩色表示像の可読性が影響を受ける可能性 がある. 実験 2 では, 表示色相の空間周波数に着目して有彩色表 示像の可読性を実験評価した.

\section{1 実験系}

17 インチのカラーCRT を上下に分け, 上部に輝度值が横方向 に正弦関数で変化する一定色相の空間周波数パターンを呈示し た．下部には空間周波数パターンの平均輝度值で同じ色相の像を 呈示した，空間周波数と色相は独立に変化させ, 被験者が上下の

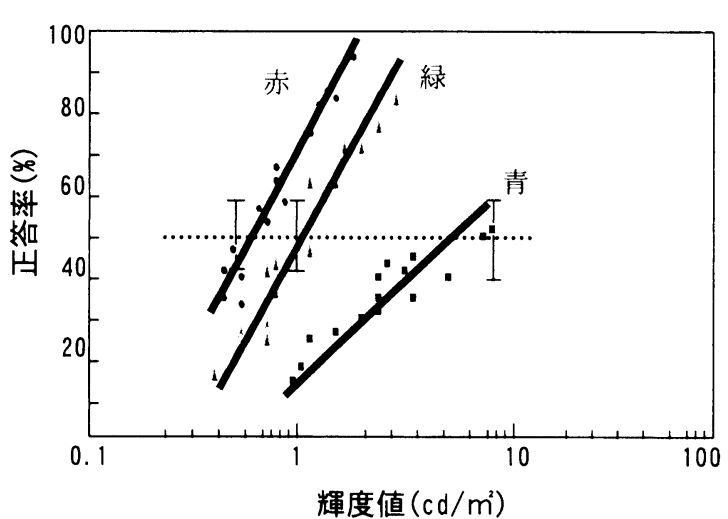

図 3 表示像輝度と正答率(低照度·低輝度条件)

Fig. 3 Correct response rates vs. luminance of the indication images (low illuminance low luminance condition).

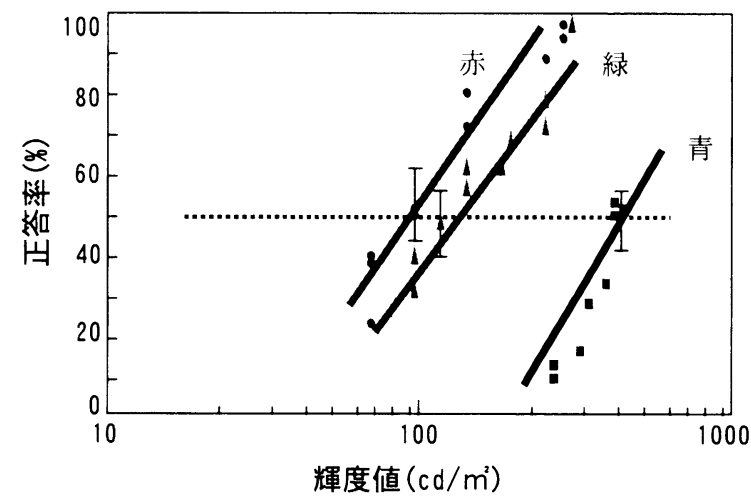

図 4 表示像輝度と正答率(高照度·高輝度条件)

Fig. 4 Correct response rates vs. luminance of the indication images (high illuminance $\cdot$ high luminance condition).

表 2 背景色と表示像の色差と正答率

Table 2 Comparison of correct response rates and color difference between the background and displayed image.

\begin{tabular}{ccc}
\hline 色相 & 色差 & 正答率(\%) \\
\hline 赤 & 50 & 75 \\
緑 & 48 & 50 \\
青 & 85 & 20 \\
\hline & & (表示輝度 $\left.1 \mathrm{~cd} / \mathrm{m}^{2}\right)$
\end{tabular}

像を区別できなくなるぎりぎりの闒值(弁別䦚)を色相ごとに計測 した，計測は上下法を用い，高周波から低周波へ，低周波から高 周波へそれぞれ 20 回, 計 40 回を 1 試行とした. 実験 1 と同様に, 背景地には黒灰色を, 色相には赤色, 緑色, 青色を用いた。 空間 周波数パターンの最大輝度值は $1 \mathrm{~cd} / \mathrm{m}^{2}$ に設定し, 平均輝度值は $0.5 \mathrm{~cd} / \mathrm{m}^{2}$ とした. 呈示パターンが存在する視野は中心 5 度以内, 被験者は色覚正常かつ自動車免許を有する 20 代男子 4 名.

補足実験として, 実験 1 の低照度·低輝度条件の実験における 輝度值 $1 \mathrm{~cd} / \mathrm{m}^{2}$ 一定の条件で, 正答率 $50 \%$ を得る視標サイズを色相 ごとに計測した．弁別闘と定量的に比較するため, 計測した 4 人 の被験者の視標サイズを平均し, 開口方向に垂直な方向の基本空 間周波数を求めた 9) 11 . 


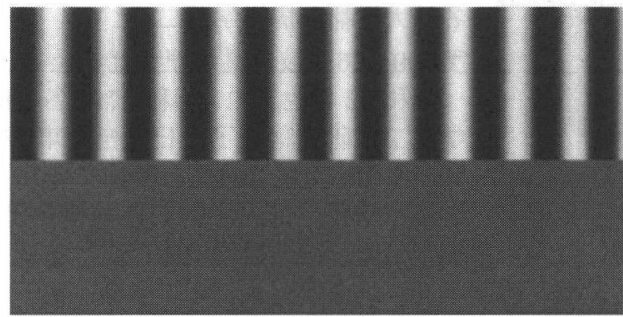

図 5 呈示画像パターン例

Fig.5 Spatial frequency and equal luminance image.

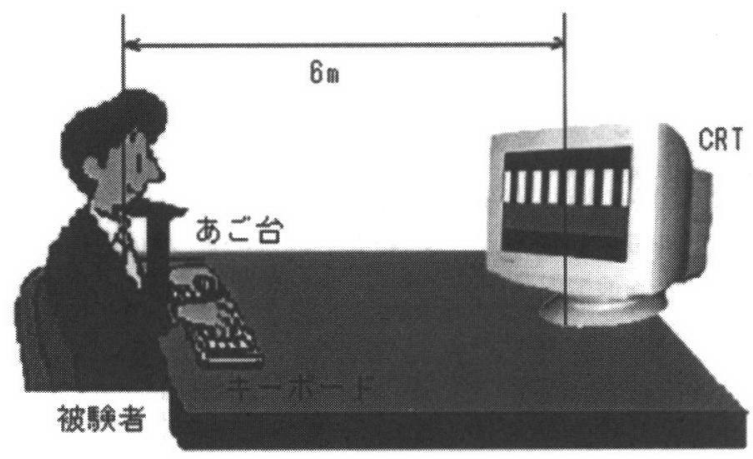

图 6 実験装置

Fig.6 Experimental set up (Measurement of the differential threshold).

\section{2 結果}

赤色, 緑色, 青色のそれぞれの弁別闇と補足実験から得られた 基本空間周波数を表 3 に示す. 弁別閥は, 赤色が最も高く, 緑色, 青色の順に低下する，この順は実験 1 における輝度值と正答率の 関係の順と整合する. 弁別闘と視標から求めた基本空間周波数と の間に良好な一致を認めることができる．これらの結果は, 低コ ントラスト条件のような劣悪な視環境条件での表示装置における 可読性が, 色相別空間周波数特性により規定されることを示唆し ている.

\section{表 3 正答率 $50 \%$ を得る視標の基本空間周波数と弁別闘}

Table 3 Spatial frequency differential threshold and basic component of spatial frequency for the Sunellen figure with $50 \%$ correct response rates.

\begin{tabular}{ccc}
\hline 色相 & 基本空間周波数 $(c p d)$ & 弁別閾(cpd) \\
\hline 赤 & 22 & 25 \\
緑 & 18 & 21 \\
青 & 15 & 17 \\
\hline
\end{tabular}

分光視感効率特性が空間周波数的には低周波成分での感度特性 を表現しており，本報告で詊価してきた中心視野近傍での表示像 の可読性は, 高周波成分での感度特性を表現していると考えられ る. 従って, 分光視感効率特性から導出した輝度値だけで, 微細 な有彩色表示像を有する自動車用多色表示装置の表示像の条件を 設定するのは，大きな問題を含んでいることが分かる．定性的に 表現すれば自動車用多色表示装置では, 表示像ごとの色選択にお
いて, 空間的に微細構造を有する表示像には赤色系表示色を, 空 間的に粗い構造を有する表示像には緑色や青色を用いることが 望ましいことを示唆している.

4. まとめ

（1）実際の運転環境でドライバから報告されていた「赤色表示 像が緑色表示像よりよく読める」という「色相の差異による知 覚の不均一」が実験室実験で正答率という指標を用いて定量 的に示された.

（2）輝度を規定している分光視感効率特性は空間周波数的には 低周波成分での感度特性を表現しており,「色相の差異による 知覚の不均一」に関わる可読性は, 表示像の高周波成分での感 度特性が大きな要因であると考えられる.

（3）自動車用多色表示装置設計では, 空間的に微細構造を有す る表示像には赤色系表示色を, 空間的に粗い構造を有する表 示像には緑色や青色を用いることが望ましい，

本研究の一部は平成 14 年度文部科学省科学研究費補助金によ って実施致しました.

\section{参考文献}

（1）和田, 岡林, 杉江, 畑田: 色相別空間周波数特性から見た自 動車用多色表示装置の表示像認識, 照学全大, p.168 (2002).

(2) Y. Yoshida, F. Maruyama, T. Horigome, and R. E. Bartlett : Multi-Color Surface Light Emitting FIPTM for Automotive Applications, Electronic Displays and Information Systems SP-565, Society of Automotive Engineers, Inc., pp.99-102, (1984).

（3）大山, 今井, 和氣編 : 新編感覚·知覚心理学ハンドブック, 誠信書房, pp.412-413 (1994).

（4）岡林, 古川, 畑田 : 自動車用ヘッドアップディスプレイにお ける前景情報と表示情報の認識について, 照学誌, p.75 (1991).

（5）日本色彩学会編 : 新編色彩科学ハンドブック, 東京大学出版 会, p.275, (1998).

(6) C. M. Cicerone and J. L. Nerger : The Relative Numbers of Long wavelength sensitive to Middle wavelength sensitive Cones in the Human Fovea Centralis, Vision Res., 29, pp.115 128 (1989)

(7) D. R. Williams : Topography of the Foveal Cone Mosaic in the Living Human Eye, Vision Res., 28, pp.433-454 (1988).

（8）坂田晴夫 : 網膜の錐体分布と三原色空間周波数特性の関係, 通学論 Vol.J65-A No.6 (1982).

(9) S. Okabayashi, T. Wada, T. Hatada \& N. Sugie : Driver's Percognition of Images in Automobile Multi-Color Display System, 9th Vision in Vehicle, pp.32-36 (2001).

（10）大石進一：フーリ工解析, 岩波書店, pp.72-80 (1989).

（11）三浦弘雅，岡林繁: 色相別空間周波数特性に基づく有色彩文 字情報の認知, 電気関係学会東海支部連大, p.240 (2002)

（受付日 2003 年 1 月 27 日 / 採録日 2003 年 4 月 11 日） 